\title{
"MY DEAR SIEGFRIED": GOSSE TO SASSOON
}

\author{
BY PAUL FUSSELL \\ Professor Fussell, a National Book Award Winner, \\ teaches English in Rutgers College of Rutgers University
}

THE Alexander Library has recently added to its Gosse collection a number of interesting letters to Siegfried Sassoon running from the twenty years from I 908 to Gosse's death in 1928. Some have been printed in Evan Charteris's The Life and Letters of Sir Edmund Gosse (I93I); others are unpublished. ${ }^{1}$ One thing they emphasize is Sassoon's assiduity in promoting his literary career, a motif he carefully omitted in The Memoirs of George Sherston, his three-volume account of his life up through The Great War. It is a work which increasingly we are agreeing to assign to the domain of fiction. One of Sassoon's lifelong problems was reconciling or at least understanding his polarities as sportsman, on the one hand, and author, on the other. As he says, "One half of me was huntingfield and the other was gentleman writer." Hemingway would show how these two identities could be reconciled, but Sassoon's problem was that he imagined that literature had to be delicate if not frail to be "beautiful." The hunting-field half of him he depicts as the healthy, thoroughly philistine Sherston; the gentleman writer half he presents as "Siegfried Sassoon," the actor and agent of recall in The Old Century and Seven More Years (1939), The Weald of Youth (1942), and Siegfried's Journey ( I945). It is entirely as the aspirant gentleman writer aged 22 that he first presents himself to the 59-year-old Edmund Gosse in 1908.

There had been a long social and familial connection between the Sassoons and the Gosses. Siegfried's mother was a close friend of Gosse's wife Nellie, and Siegfried's Uncle Hamo, the sculptor, had been best man at Edmund's wedding. To young Siegfried Gosse appeared not only eminent but, as the friend of Swinburne, Hardy, and James, advantageously situated to recognize talent and then

\footnotetext{
1 Of the letters quoted here, the following are not in Charteris: Dec. 6, I9II; May 13, I917; May 29, I917; Aug. 8, 1918; Sept. 8, I918; April 11, 1919; Oct. 25, 1919; Filson Young to W. J. Turner, Sept. I9, I 921 ; Sassoon to Young, Sept. 21 , 1921 ; Sept. 23, 1921; Sept. 26, 1921; March 27, 1928.

2 The Weald of Youth (London, 1942), p. 208.
} 
to publicize it. Gosse appeared the quintessential literary man. $\mathrm{He}$ was a copious writer, author of poems, essays, literary studies, appreciations, biographies, "romances," as well as an indefatigable maker of editions, catalogs, and bibliographies. His compelling memoir $F$ ather and Son appeared just a year before Siegfried decided that Gosse might be the one to assist his own literary career. Gosse was less a critic than a literary journalist, and although his pretensions to scholarship had scarcely survived John Churton Collins's famous exposure in the Quarterly Review (October, I 886) of the manifold airy carelessnesses in his From Shakespeare to Pope ( 1885 ), the canon of English Literature was still largely what Gosse said it was. Aspiring to become a book-collector at age I7, Siegfried hoped that the books he accumulated "would be as old as possible, or else ... mentioned in Mr. Gosse's History of Eighteenth Century Literature [ I 889], which was my sole guide to what was worth getting out of catalogues." ${ }^{3}$ The eminent man of letters who, as Siegfried said, "had mingled with so many of the majestic immortals-had talked with Tennyson, breakfasted with Browning, and supped with Swinburne,"” was clearly worth cultivating by the young poet who said later of his adolescent ambition, "I too would some day write like Tennyson."

Sassoon's first bid for Gosse's admiration was his slender volume Orpheus in Dilcryum (1908), his second book of poetry, privately printed like his Poems of I 906 . The work was a flaccid verse play, later characterized by Sassoon as "a typically juvenile performance ... in the form of an unactable one-act play which had never quite made up its mind whether to be satirical or serious. . . ." Gosse's reply, enamating from his handsome house at if Hanover Terrace, overlooking Regent's Park, was generous, but its last sentence seems to hint that young Siegfried is going to need lots of prosodic discipline:

\section{Dear Mr. Sassoon}

March 28, I 908

It was very kind of you to send me your delicate and accomplished little masque 'Orpheus in Dilœryum,' which I have

\footnotetext{
${ }^{3}$ The Old Century and Seven More Years, ed. Michael Thorpe (London, 1968), p.

${ }^{4}$ Weald of Youth, p. 177.

5 The Old Century, p. 87.

${ }^{6}$ Weald of Youth, p. 15.
} 234. 
read with pleasure and amusement. It reminds me of some of the strange entertainments of the early Renaissance, and of Italian humanism generally.

("What exactly was Italian humanism, I wondered," Sassoon noted later.) ${ }^{7}$ Gosse concluded by gently reminding Sassoon that poetry is art and technique as well as expression: "I hope you will make a prolonged study of the art of poetry, and advance in it from height to height."

Sassoon's next submission was his volume Sonnets (1909), which, on Dec. 5, I909, Gosse wrote that he had read "with . . . no little pleasure." At the same time, he warned against vagueness, invoking a "period" Ruskinian image to make his point:

However frail and fantastic the thought you embody may be, if it is worth embodying at all, it must have its essence precisely visible, as a painter must draw a melting cloud on the horizon correctly, or at least recognizably, if he draws it at all. Your sonnets are not firmly enough drawn.

Gosse next delivers prosodic admonitions, noting "four lines in these few poems which are absolutely impossible to scan without an offense against language." Serious and humble prosodic studies are enjoined: "I think a young poet should have learned the technique of his art very thoroughly before he dares to take liberties with his prosody." Gosse goes on to remind Sassoon that from thence "is not English": "I hope in these days of outrage, you will defend the purity of the English language," "a responsibility," Sassoon observed later, "for which I was as yet altogether unprepared." "Even Gosse's friendly close manages to glance shrewdly at Sassoon's obligations to technique: "I look for great things from you, and I shall always be particularly happy to hear how you and your art [my emphasis] are getting on."

The study of poetic technique counselled by Gosse Sassoon found impossible. Any improvement in prosody or idiom would have to come by instinct or practice rather than study. Indeed his attempts to become systematically a gentleman writer only exposed the more his other identity as a fox-hunting man. As he says, his "unmethod-

${ }^{7}$ Ibid., p. 16.

${ }^{8}$ Ibid., p. 88. 
ical investigations of verse technique only resulted in a persistent feeling that I should do better to be out of doors instead of burying my nose in a book." And he tells of a later occasion when he returned to his London rooms exhilarated by the Russian Ballet during its famous season in the summer of 1914: "Twiddling my fading carnation as I sat by the writing-table, I thought how prosily methodical my dictionary looked, lying there beside the treatise on prosody which had repelled all my efforts to make mental headway with it."10 Again, he says, "I have always found prosody a perplexing and unassimilable subject. . .."11

Sassoon next sent Gosse two privately printed pamphlets, Twelve Sonnets and Poems (I9II). Gosse replied with this encouraging letter on Dec. 6, I9 I :

\section{Dear Siegfried Sassoon}

I am very glad to receive your two new pamphlets. I think you are gaining firmness of thought and sleight of hand. "The Shepherd," "Arcady Unheeding," and "The Goose-Boy" are delightful. Practice this delicate mode of writing, more and more. In lyrics, do not leave yourself any laxities: I notice here and there a rhymeless ending where the ear calls for a rhyme. Cultivate the beautiful richness of rhyme. I fancy you should work more. Write, write, write-even if conscience makes you burn and burn.

My congratulations and my very sincere hopes and wishes follow your effort.

Yours most truly

Edmund Gosse

For five years Sassoon tried to impress Gosse. He felt that he finally succeeded only in I9I3, when he sent him The Daffodil Murderer, his parody of Masefield. On Feb. I3, I9I3, Gosse responded with the enthusiasm he displayed with any writing he really liked: "'The Daffodil Murderer' . . . is a very clever, brilliant thing, and displays powers which I had not expected from you." Gosse is now so impressed that he invites Sassoon to send

${ }^{9}$ Ibid., p. 209.

${ }^{10}$ Ibid., p. 261.

11 Siegfried's Journey, 1916-1920 (London, 1945), p. 107. 
some work to Edward Marsh for his anthologies of Georgian poetry. "It is time," Gosse concludes, "for you to begin to tilt up the bushel under which your light has hitherto been burning." With this evidence that he was now Making It, Sassoon was ecstatic. As he recalls, "It is no exaggeration to say that I read this letter with a sort of blissful stupefaction. . . . Mr. Gosse's letter . . . was evidently intended to show that he no longer doubted my ability to become an effective writer."12

During the early stages of the War, the relation between the two remained that of the powerful donor of approval and the humble suppliant. Sassoon joined the Army the day after Great Britain entered the War. As late as March 20, I916-four months before the disaster on the Somme which did so much to clarify the vision of the participants about the contours of the modern world-Gosse is to be found cautioning Sassoon against an excessively modern versification: "I hope you will not overdo the irregularity of versification. Now and then a prosodical irregularity may be a beauty, but the ear hates to be caught up by an incessant jolt. The laws of verse which were good enough for Keats and Wordsworth are good enough for you." Sassoon could be forgiven at this point for perceiving a sardonic analog: The laws of attack which were good enough for Wellington are good enough for you, despite the invention of the machine gun. Yet Gosse's letter overflows with generosity and genuine friendship. "Your letters give me the great pleasure," he says.

But trouble was inevitable. The rift between Front and home was as unavoidable between Sassoon and Gosse as it was everywhere else. It was not long before Gosse was finding Sassoon's poems from the Front too cynical, realistic, and brutal. Sassoon was not likely to continue a warm wartime friend of the Gosse who could write Earl Spencer (Nov. 23, I914): "My son is in the Army now, very active and happy. His mother and I are completely pleased, and if we had ten sons we would give them all." ${ }^{13}$ That sounds too much like Robert Graves's Little Mother to be believed, but it constituted standard rhetoric at the outset of the war, and once he had experienced the trenches Sassoon had to fall away from that attitude and

${ }^{12}$ Weald of Youth, p. I 35.

${ }_{13}$ Evan Charteris, The Life and Letters of Sir Edmund Gosse (London, 1931), p. 372. 
that idiom. As he testifies, "Gosse ... had a preference for idealized soldier-poems when first-hand evidence was forthcoming from the Front."14

Gosse dearly loved a lord, and his work as Librarian of the House of Lords from I904 to I9I4 was infinitely precious to him. A new note of asperity creeps into his letter to Siegfried of Feb. I7, I9I7. On that date Siegfried had published his 30-line poem "Conscripts" in the Spectator. With its scurvy treatment of such Georgian literary properties as "attractive attitudes," "magic," "rhyme," and "romance," Sassoon's poem might seem a direct assault on Gosse's well-meant literary gentility, as well as a precipitate flight from the moony romanticism of Sassoon's early verses which Gosse had commended. "Conscripts" begins:

'Fall in, that awkward squad, and strike no more

Attractive attitudes! Dress by the right!

The luminous rich colours that you wore

Have changed to hueless khaki in the night.

Magic? What's magic got to do with you?

'There's no such thing! Blood's red, and skies are blue.'

The officer drilling the awkward squad continues:

I drilled them till they cursed my raucous shout.

Love chucked his lute away and dropped his crown.

And rhyme?

Rhyme got sore heels and wanted to fall out.

Their training finished, says the officer,

I shipped them all to France,

Where most of those I'd loved too well got killed.

Rapture and pale Enchantment and Romance,

And many a sickly, slender lord who'd filled

My soul long since with lutanies of sin,

Went home, because they couldn't stand the din.

But unlike the aesthetic, effeminate "lords,"

the kind, common ones that I despised

... stood and played the hero to the end,

14 Siegfried's Journey, p. 28. 
Won gold and silver medals bright with bars,

And marched resplendent home with crowns and stars.

Intensely pained by this, Gosse wrote the poet immediately:

Feb. I7, I9I7

My dear Siegfried

I have just been reading with admiration your striking verses called 'Conscripts' in the Spectator. But there is a phrase in them which I sincerely hope you will modify before you republish them. You say 'Many a sickly, slender lord . . . went home.' This is a cruel and unworthy libel. No section of the whole community has shown more courage or devotion than the class you have so gratuitously sneered at. The House of Lords has sacrificed, in proportion, more of its members and connections than any other in the country. I am unable to guess who the 'many slender, sickly lords' are whom you have met on their way skulking home. I have heard of none, and I think your attack on the class, in order to butter up the 'common ones,' is a very unworthy one. Do not let it deform your book, from which I have been expecting great pleasure.

\section{Yours affectionately}

\section{Edmund Gosse}

Gosse's uneasiness about Sassoon's current work surfaces again but more coyly on May I3, I9I7, when he acknowledges the gift of The Old Huntsman and Other Poems, published ten days earlier. Collected here Gosse found such outspoken satires of home-front complacency as "Blighters," "They," "The Hero," and-worst of all- "Conscripts" again, with the peccant allusion to the lords conspicuously unamended. Forgoing as apparently useless the appeal direct, Gosse now writes with shrewd calculation, affecting anxiety over the book's reception:

My dear Siegfried,

May I 3, I9I 7

Your volume has come, and your very kind letter. I like the former even better than I thought I should: your recent pieces are solid, vigorous and full of substance. I shall look forward very anxiously to its reception; and you must be glad to have it off your hands. 
Thank you for what you so generously say about my 'Swinburne' [published April, I9I7].

\section{Affectionately \\ Edmund Gosse}

Gosse's next letter, written a little over two weeks later, is a superbly political document. He seems to have been brooding over Siegfried's "predicament" and considering how to attract him back from contempt to respectability and normal poetic usages. In short, considering how to repair some of the damage.

My dear Siegfried

Gisburne ...

May 29, I9I 7

Your most amusing letter has just arrived here, where I am spending ten days alone with my old friend, Lord Ribbesdale. ... I want to tell you that I saw the Poet Laureate just before I came away, and he had seen your Poems in a shop. He could not cut open the leaves, but he read where he could. He is a rare and grudging praiser, and therefore I was much gratified at his warm commendation of several of your pieces. He said you had 'got more of the real stuff in you' than almost any other of your generation.

I want you to send him a copy of your book, with a nice respectful inscription, and you might even write a note saying that you are doing so because you heard from me that he had expressed himself kindly about the book. . . . Robert Bridges Esq. P. L. Oxford is quite enough address. ...

\section{Ever sincerely}

Edmund Gosse

Further letters from Gosse during I9I 8 are largely gossipping, with fairly vague commendations of Sassoon's literary performance: e.g., June 25, 1918: "You have certainly been writing admirably." On August 8, I9 18, he writes: "Your last little volume of poems [Counter-attack] has attracted, I think, a good deal of attention. You must be careful how you write now, for the Eye of the Lettered Public is upon you. You have the chance of making a great reputation." And again, on Sept. 8, I9I8, prudent counsel: "I am delighted to hear of your writing 'with extreme caution.' Technique 
is all you need." After his defeat on the matter of the sickly, slender lords, Gosse stops remonstrating with Sassoon about his themes and restricts himself to stylistic and even typographical observations. The relation of the two men from I9I6 on resembles the relation between Gosse's Father and Son. Two days after the Armistice Sassoon lunched with Gosse at Hanover Terrace. "It was more than a year," he wrote later, "since I had seen Mr. Gosse, who had viewed my anti-war activities with disapproval and distress." But there were mitigations: "The success of Counter-attack had, however, afforded him a sort of scandalized satisfaction. . . . I was now welcomed as a triumphant prodigal, no reference being made to my pacifist aberrations." 15

By April I I, I 9 I9, Gosse seems entirely to have forgiven Sassoon his little wartime excursion into rebellion, and on that date he counsels him man-to-man-the letter is headed Confidential-about the problems of keeping the 38-year-old minor poet-critic Lascelles Abercrombie afloat without supplying him with greater bouyancy than he deserves. Gosse's suave attempt to impose a check on Sassoon's impetuous generosity is typical of their whole Father-Son relation:

My dear Siegfried

Your very kind and generous movement to help Lascelles Abercrombie is wholly in accordance with my own feeling. I have been for a long time very anxious to improve his position, and I have made several efforts in that direction. I am hoping at this moment that a certain Lectureship in English Literature may be secured for him.

But I am not quite sure that a pension from the Civil List is quite the right thing. $\mathrm{He}$ is still very young, and I think you will agree with me that it is a questionable matter to pension an able-bodied man in the early prime of life.

You are aware, I suppose, that L.A. receives a third of all the proceeds of Rupert Brooke's writings in prose and verse? I happen to know that this amounts to a very considerable sum, which at present is increasing each year. This forms, in itself, a kind of pension, and should not be overlooked in any estimate of L.A.'s position.

${ }^{15}$ Ibid., pp. 99-100. 
Speaking to you in all secrecy, there is to be observed in L.A. a certain-I will not say tendency to laziness--but languor in taking up work. It is a feature of the case which has given me some disquietude. I am in doubt whether, at his present time of life, it is good for him to be further helped with money which he has not earned, until he has exhausted every means of getting employment of a suitable kind. You are doubtless more intimately acquainted with him than I am, and I shall be very grateful for any advice you are willing to give me, for I have a sincere sympathy with his needs and a very genuine admiration of his talents. Write to me again.

We all send you our love, and I am ever

Most truly yours

Edmund Gosse

To maintain his status as a critic whose views mattered, Gosse poured out letters of congratulation to authors young and old as their works appeared or were sent for his approval. Sassoon was included, receiving praise for his poem "Falling Asleep" in The Nation and Athenaeum for Oct. 25, 1919 ("You get better and better. Hurrah!”) and for his privately-printed volume Picture Show. Most of these poems Gosse is happy to approve for their "rare beauty," but he still feels, in a letter of July 5, I9I9, that Siegfried needs to be more careful: "I only now ask for a little more self-restraint and a little more technical discipline. You have it in your hands to decide whether you will go right up among the notable English poets."

But an episode in I92 I brought a very different kind of letter from Gosse. He had apparently recommended Sassoon's friend W. J. Turner as an occasional reviewer of plays and books on the theater to Filson Young, editor of The Saturday Reviero, and in doing so imagined that he was doing Turner a favor. Turner, assisted by Sassoon, rejected the offer with some contumely (he was already drama critic on the London Mercury), and Filson Young responded on Sept. I9, I92 I :

Dear Mr. Turner,

I am sorry you feel that you cannot condescend to do any reviewing for the 'Saturday'- because as you must know one does not entrust dramatic criticism to anyone whose work has not been well tried in every direction. I had hoped that you 
would not have felt it beneath you to do what Mr. Gosse does for us....

Yours very truly, Filson Young.

Sassoon's contribution to this little war of insults was an extremely offensive brief note to Filson Young, written Sept. 21, I92 I :

Dear Sir

My friend W. J. Turner has asked my advice with reference to your letter (dated Sept. I 9 th, and beginning 'I am sorry you feel that you cannot condescend to do any reviewing for the "Saturday"').

I have advised him that, before doing any work for your 'Review,' he should insist on your sending him a certificate of your circulation. Provided that your circulation exceeds 500, he will be very pleased to do an occasional review.

I very much hope that you will be able to satisfy our mutual curiosity.

Yours truly

Siegfried Sassoon

Filson sent Sassoon's note to Gosse, who two days later exploded in Siegfried's face:

Dear Siegfried

Sept 23, I92 I

You must be mad to fling about silly and insolent letters like the enclosed.

As for W. Turner, I was anxious to do him what is called 'a good turn.' He accepted my offer to do so. Pray inform Mr. Turner that I shall never trouble him with any civility again.

As for you, when I reflect on the care I have taken of you ever since you were a very crude and unpromising youth in whom I alone saw a future, I am disgusted at your arrogance. You are now brilliantly and deservedly famous, and you think you can turn with impunity on the aged friend who had the presumption to believe in you when nobody else did.

Edmund Gosse

Sassoon immediately sent a note of apology, and was forgiven by Gosse-handsomely-on Sept. 26, I92 I: "The incident is now as if 
it had never been." Normal relations resumed. Gosse wrote the next year to praise Sassoon's volume Recreations but registered the usual cautions about the importance of rhyme and meter. On Dec. 22, 1922, he asks Siegfried to help him meet Edmund Blunden, and on Jan. I4, I923, indicates his pleasure that Blunden and Sassoon have dined with him at the Marlborough Club: "I was delighted with your young friend-he looked like a chinchilla, with his grey clothes, sharp nose and wonderful eyes. What eyes! Those of Keats must have had that expression." But in the same letter he mentions his deteriorating health-he was now 74-and few subsequent letters fail to mention his increasing weakness. But Sassoon keeps up a steady stream of his little books, and graceful notes of acknowledgment and praise keep coming back. And of sincere thankfulness for Sassoon's young friendship. Gosse concludes a letter of Dec. 28, I926: "Well, goodbye in 1926 , and thank you for all your kindness to me in the past year. I value your friendship very highly indeed, and as long as I am not too decayed to appreciate it, I beg you will continue it."

In I 945 Sassoon remembered a meeting with Gosse just after the Armistice. "During our talk," he writes, "he strongly urged me to undertake a long poem which would serve as a peg on which-for the general public-my reputation could hang. He suggested that I might draw on my sporting experiences for typical country figures - the squire, the doctor, the parson, and so on. He was, of course, partly influenced by anxiety that I should divert my mind from the War. At the time I thought the idea unworthy of serious consideration."16 Too much like a replay of George Crabbe's The Parish Register or The Borough, perhaps. But Gosse's idea took root, and early in 1927 Siegfried sent Gosse some of the MS. of Memoirs of a Fox-Hunting Man, destined to stand as the first volume of The Memoirs of George Sherston. Gosse was excited by its uniqueness:

My dear Siegfried

$$
\text { Jan. } 27,1927
$$

I have had a very crowded week, and only able very occasionally to give half an hour to your MS., of which I have read Parts I and II ["Early Days" and "The Flower Show Match"]. But I think you will be anxious for a word from me, and so I write provisionally to say that I am delighted with it

16 Ibid., pp. I00-I0I. 
so far. There is no question at all that you must go on steadily. It will be an extraordinarily original book. . . .

But as he read further he was distressed to discover the idyllic gradually yielding to the satiric, and on Feb. 3 he remonstrated: "You are not called upon to draw a sarcastic picture of a slack and idle young man. . . . Remember, no satire and no sneering! Hunting has to be the subject and Dixon [Sherston's groom friend] has to be the central figure." Siegfried received further encouragement on March 27, 1928: "I rejoice that your tale of a Man and his Horse progresses. I am eager to read it completed." But Gosse was dead (May I6, 1928) before the book was published on Sept. 28.

Gosse's status is low at the moment. His contempt for Joyce and Pound, his inattention to Yeats, his failure to notice the work and influence of a young American in London named T. S. Eliot-these lapses have weakened his claims as a critic and damaged his reputation even as a very perceptive literary gossip and manipulator. A manipulator has got to know what is going on, and too many phenomena are escaping Gosse's notice. John Gross sees him as largely a "snobbish, prickly, disingenuous literary politician" and concludes that "the impression which remains longest is one of artfulness and calculation, of literature subordinated to petty social ends." ${ }^{\prime 17}$ True enough. And yet for Sassoon Gosse did much. His constant reminders about the importance of technique did help Sassoon refine a style which at first, in both verse and prose, was awkward, even unpleasantly rural. He certainly steadied the shy, boyish, unsystematic young Sassoon and gave him the sort of self-confidence whichironically-finally caused him to "go too far" in the Turner affair. But perhaps most important, Gosse planted in Sassoon's mind-if unwittingly and quaintly - the idea for his masterpiece, The Memoirs of George Sherston. For that, posterity, while smiling at his little snobberies and superficialities, may forgive him much.

17 The Rise and Fall of the Man of Letters: Aspects of English Literary Life Since 1800 (London, 1969), pp. 158, I63. 